In the workers of Termes favipes the oenocytes are much more difficult to detect. They are flattened cells imbedded in the pleural hypodermis near the stigmata. It is their size which mainly distinguishes them from the hypodermal cells; the latter measuring only $8 \mu$ while the former measure $37 \mu$.

Thysanoptera. Oenocytes occur in compact metameric clusters in a species of Phloeothrips very common on the blossoms of Chrysanthemum leucanthemum during July and August.
These clusters occur in at least six of the abdominal segments, possibly in eight, but as they diminish in size very rapidly from before backwards, I am not sure that I have found them in the 7 th and 8th metameres. The clusters lie in the pleural region well out in the body cavity and each consists of some 8 or ro cells which from mutual pressure are often very irregular. The cells measure r $8.5-26 \mu$ in diameter - their nuclei $3-6 \mu$. They are perfectly distinct from the fat-body and blood corpuscles.

\title{
A NEW GENUS AND SPECIES OF TABANIDAE.
}

\section{BY J. M. ALDRICH, BROOKINGS, SOUTH DAKOTA.}

The general appearance of the fly is that of a particularly fine large silvery Hippoboscid, with brown wings. Nevertheless, an examination shows it to be truly Tabanid in every respect; in fact, I was at some loss for a while to fix upon a set of generic characters which would clearly separate it from all the present genera of Tabanidae. The venation is normal; the antennae resemble Pangonia in shape and number of annulations; the face is that of Chrysops. The upper corner of the eye, making an angle of about 7o degrees, and not in the least rounded off at the tip, but rather produced a little in a very fine point, beyond which is an impressed line, running to the occiput, is one of the best characters. The general proportions of the body, also, are different from those of any other members of the family known to me.
Its habits are unknown, but from its appearance the conclusion looks probable that it lives like a Hippoboscid upon some bird or mammal. Still, there are no modifications of structure that give strong support to this theory. Its claws are distinctly larger than those of Tabani of its size, and the large pits at the bases of the hairs on the first and second antennal joints seem to indicate an unusual development of the sense of touch in this region; both of which peculiarities are not without weight.

\section{Goniops n. gen.}

Spurs present on hind tibiae, absent from front ones. Eyes narrow, terminating above in an acute angle. Ocelli present. Front broad in female, the callosity longitudinal. Proboscis in repose directed forward. Thorax strongly arched, subglobular. Abdomen (from tip of scutellum) not longer than, and head but about half as wide as, the thorax. 
G. hippoboscoides, n. sp. + . Head almost uniform light yellow, between the ocelli tinged with brown. Eyes black, bare, not approximated to each other. Front broad, wider anteriorly, with yellow pollen on the sides, a longitudinal callosity more whitish, extending from the ocelli to the beginning of the antennal prominence; in dried specimens a variable impressed line on each side of this callosity. Antennae situated on a distinct transverse prominence, yellow, the third joint more reddish; second joint almost annular, third tapering quite symmetrically, composed of eight annuli. Face yellow, strongly protuberant, shining. Proboscis reddish, directed forward, reaching but little beyond the antennae. Palpi slender, long, yellow, with yellow pollen and aburudant blackish hairs. Posterior orbits wide, conspicuous, with yellow pollen.

Thorax whitish yellow below, more brownish above, with minute, appressed, silvery yellow pile; on the anterior border just a trace of a slender, median, reddish line; on each side a broad, indistinct reddish stripe, interrupted along the transverse suture. Scutellum short, as wide as the head, yellow.

Abdomen short, broad, covered with appressed shining silvery-yellow pile; seven visible segments, the last narrow, but little protruded, showing a distinct emargination.

Legs uniformly light yellow, the claws black except at base. Spurs of moderate size on middle and hind tibiae.

Wings hyaline, with a deep brown cloud extending across them, including the following parts: the stigma, all of the marginal cell except the proximal end, all of first submarginal, all of the second except tip, all of the first posterior except posterior half of the distal end, the proximal half of the discal, all of second basal, and middle of anal. There is a characteristic small clear spot in the second basal, at the anterior distal angle. The cloud is clearly defined behind, but fades more gradually in front. The branch of the third longitudinal vein shows a tendency to emit a stump of a vein. In one of my specimens the vein separating the third and fourth posterior cells is obsolete for the greater part of its course.

Length $\mathrm{I} 2$ to $\mathrm{I} 3 \mathrm{~mm}$. Width across expanded wings, $28 \mathrm{~mm}$.

Described from two female specimens, received from Mr. Henry G. Klages, Jeannette, Northumberland Co., Penn.

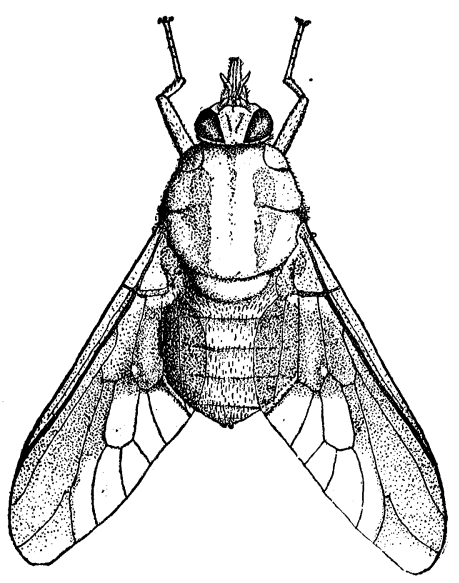

FIG. I.

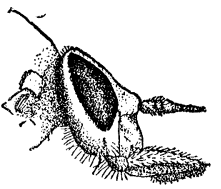

FIG. 2.

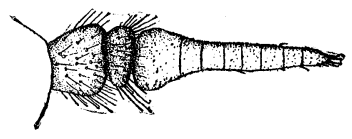

FIG. 3.
Fig. I shows the insect from above, the wings being diagrammatic. Fig. 2 is a side view of the head. Fig. 3 an antenna.

Miscellaneous notes.-Klemensiewicz, at the last December meeting of the zoological and botanical society of Vienna, stated that in the preceding summer he had observed hundreds of Pieris rapae flying 

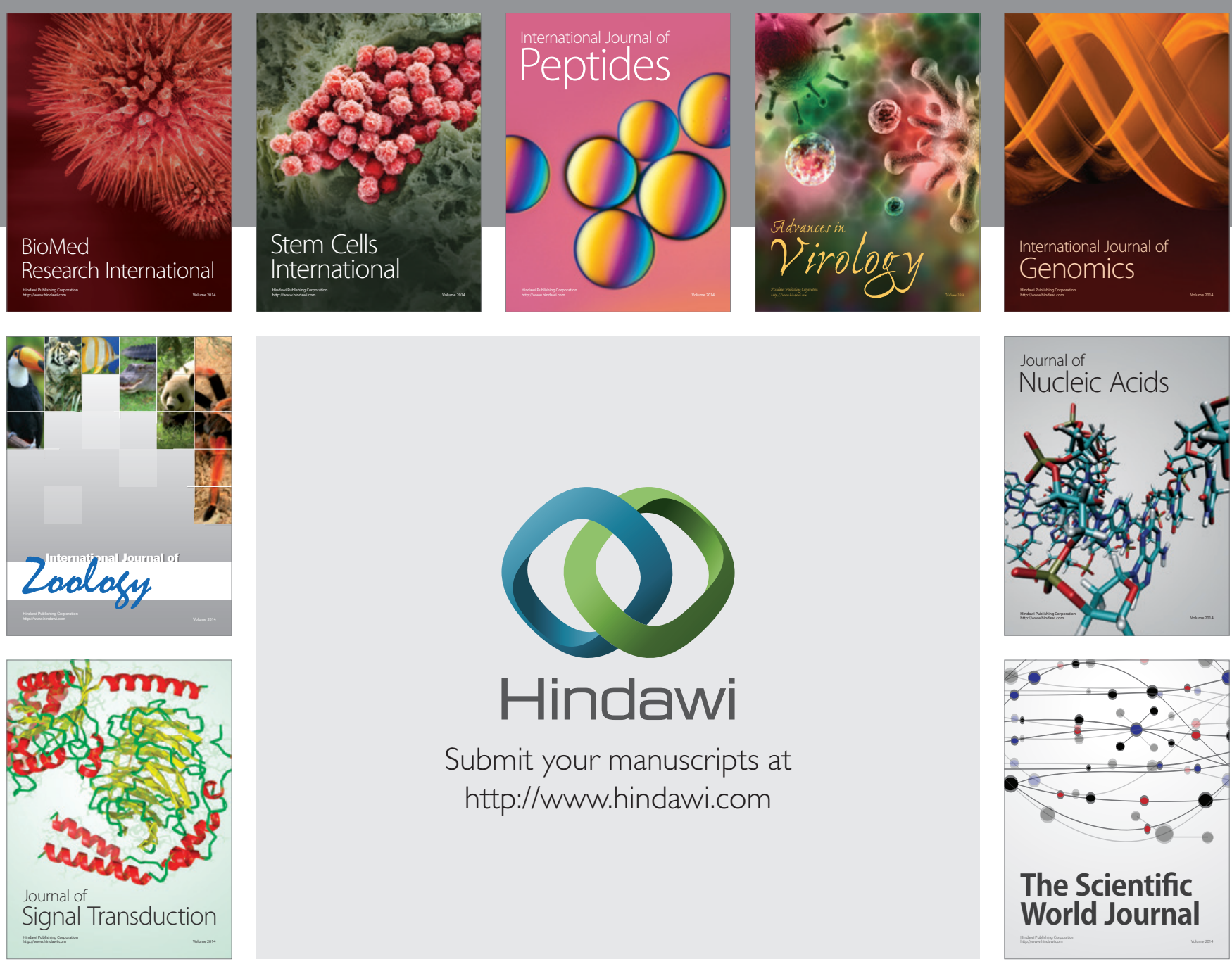

Submit your manuscripts at

http://www.hindawi.com
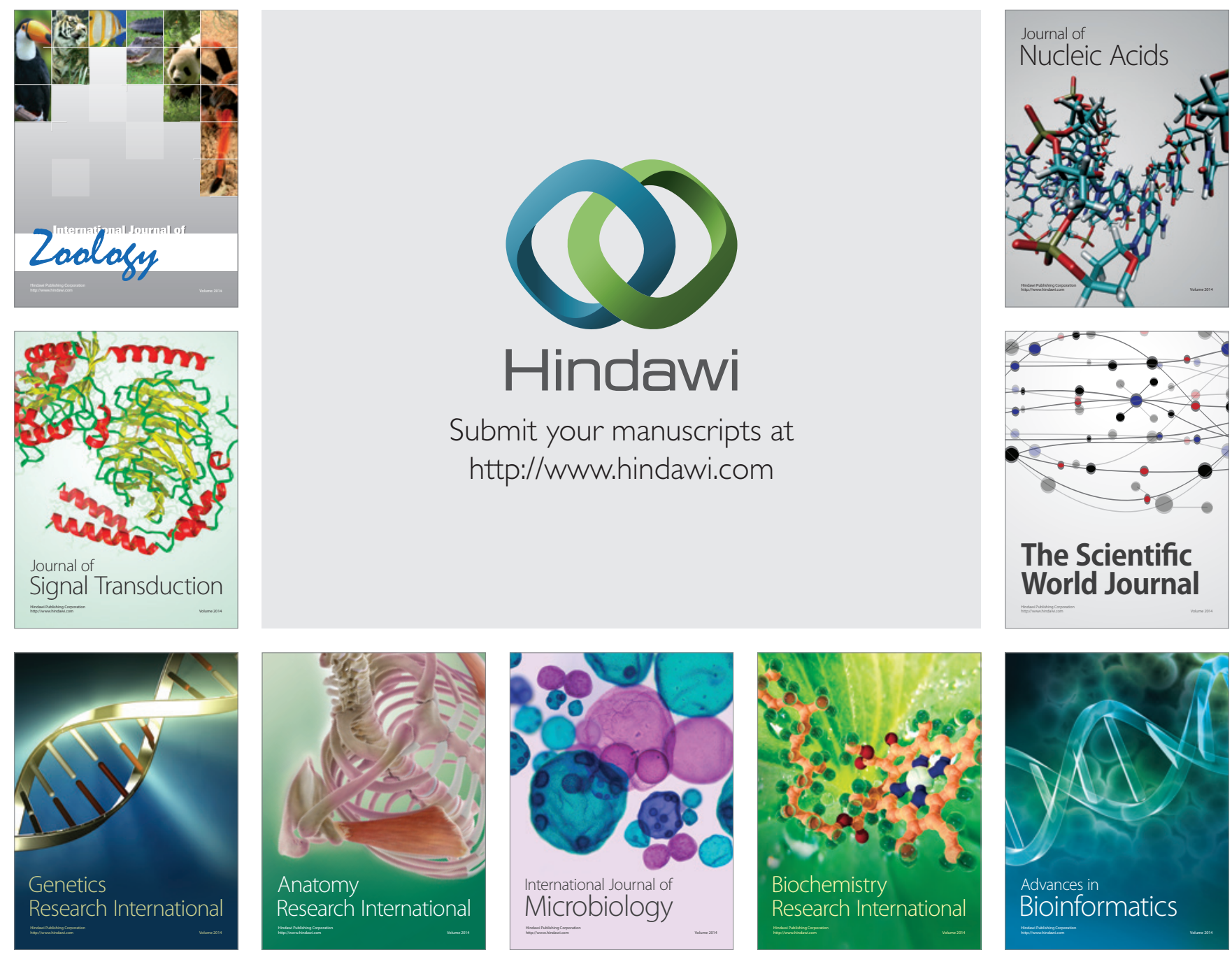

The Scientific World Journal
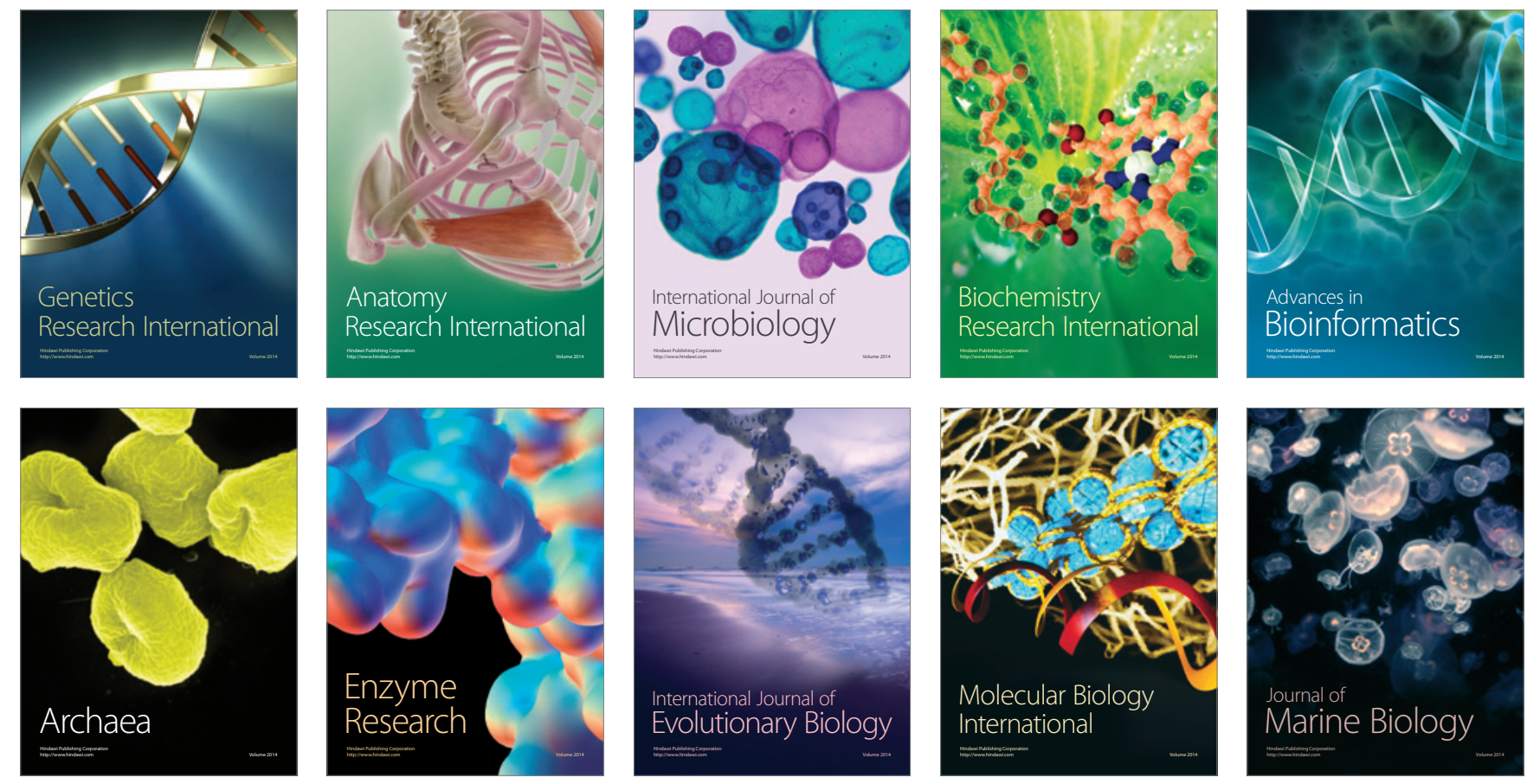